Geological Survey (Scotland); Dr. J.-B. O. Sneeden, lecturer on heat engines, Royal Technical College, Glasgow ; Dr. W. E. Swinton, curator of fossil reptiles and amphibia, British Museum (Natural History); Henry Wade, senior lecturer in clinical surgery, University of Edinburgh.

\section{Royal Horticultural Society}

THE unveiling of a plaque commemorating the foundation of the Horticultural Society in 1804 (designated 'Royal' in 1861, during the presidency of the Prince Consort), the initial proceedings of which were conducted in a room at Messrs. Hatchards, booksellers, Piccadilly, London, was the occasion of a representative gathering on March 7 at the firm's establishment, which is on the site of the older house. It is claimed that London annals do not provide any precedent recording in this way the foundation of a society having scientific relationships. The plaque has been placed on the face of the building in Piccadilly, whilst an illuminated record, inscribed with the names of the original promoters, is placed inside. These were: The Right Hon. Charles Greville, Sir Joseph Banks, John Wedgwood, R. A. Salisbury, W. T. Aiton, William Forsyth, and James Dickson. The unveiling ceremony was performed by the Hon. Henry McLaren, president of the Society, and Mr. Gerald Loder, past president.

Ar the original meeting of the Horticultural Society in 1804, John Wedgwood (1766-1844) was chairman. He was the eldest son of the illustrious Josiah Wedg. wood, and was strongly attached to horticulture, notwithstanding the limitations of the period. An early paper of his dealt with the propagation of dahlias. Some proposals that Wedgwood drew up, accompanied by useful notes, were largely instrumental in bringing the Society into being. He had observed the rise of societies for the improvement of agriculture-the British Mineralogical Society of that time was actively engaged in examining specimens of earths or soils to aid the science of husbandry-but no organisation existed for the sole purpose of encouraging horticulture. Hence, the object of the newly formed Society was the collection of information respecting the culture and treatment, culinary as well as ornamental, of plants and trees, and the publication of papers on horticultural subjects. From modest beginnings, the Society has now achieved a membership of 27,000.

\section{Faraday's Work in Electrochemistry}

The subject of Sir Harold Hartley's Friday evening discourse at the Royal Institution on March 4 was "Michael Faraday and Electrochemistry". From 1832 until 1834 Faraday was mainly occupied with electrochemical researches. He first showed that amounts of electricity which produced the same effect on a galvanometer also liberated the same amount of iodine when passed through a solution of potassium iodide. He then went on to systematic investigation of the amounts of different elements which are liberated when the same current is passed through a series of solutions or fused substances, and established the two fundamental laws of electrolysis which still stand as the quantitative basis of electrochemistry. $\mathrm{He}$ investigated also the mechanism by which a current passes through an electrolyte, and his ideas were crystallised in the nomenclature which he devised with the help of Whewell. All his new names-ion, anion, cation, electrode, and electrolysis-we use to-day with the significance which Faraday gave to them. In addition, he explored the source of the energy of the voltaic cell and forecast its relation to the affinity of the chemical reaction taking place in the cell. With the help of extracts from Faraday's diary, Sir Harold traced the development of Faraday's electrochemical work, repeating the decisive experiments which were the milestones of its progress. Faraday's electrochemical researches rank among the highest of his achievements. They were carried out in a short space of time with amazing economy of effort--it took him only two days to establish a connexion between the quantity of electricity and the amount of chemical action due to it-thanks to the combination in Faraday of brilliant imagination, unerring instinct for essentials, and unrivalled mastery of experimental technique; and his main conclusions still hold good to-day.

\section{The Aryans}

Sir ARTHur KeIth's Frazer lecture on "The Aryan Theory as it stands To-day", which was delivered in the University of Glasgow on March 4, was lacking neither in courage nor in imagination. Much water has passed under the bridge since Max Müller was accused of confusing race and language. Sir Arthur, holding that race and language are two aspects of one problem, nevertheless admits that for clearness we should have one name for the languages of Europe and another for its peoples, namely 'Caucasian'. From a reconsideration of the problem in the light of the evidence which has accrued recently from Ur, Kish, and Susa, and a survey of the distribution of racial types in early times, he derives the Caucasians from the plateau extending from Mesopotamia to India, for which he suggests the name 'Gedrosian'. In rejecting Europe as the place of origin of the Aryan tongues and practically reverting to the area west of the Pamirs put forward by Max Müller, Sir Arthur relies on the evidence of prehistory that down to somewhere about 3000 B.c. the culture of Europe was of too rudimentary a type and its inhabitants too few to make it probable that migration was to, rather than from, the highly organised agricultural communities of the east. It will be seen that Sir Arthur gave his hearers much material for careful pondering, his views implying a frank acceptance of racial and linguistic anomalies difficult to explain on any theory. He went further and asked of the Aryan theory that it should explain the triple racial zone of Europe and the diffusion of the Aryan tongues.

\section{Forecast and Fact in Science}

THE fourteenth annual Earl Grey Memorial lecture of Armstrong College (University of Durham) was given on March 3 by Dr. R. A. Sampson, Astronomer 
Royal for Scotland, on "Forocast and Fact as seen by an Astronomer". Dr. Sampson began by showing how man has transformed the world by his intellect, pointing out that such discoveries as those of Michael Faraday will live for ever, while the work of man's hands will crumble away. The world is growing more and more dependent upon science, and the changes brought about by science are for the good of humanity. Yet man cannot become superior to Nature: Nature is complicated, and the physicist is apt to go too far when he views it as something precise when it is really something vast, the mysteries of which can only be guessed. Forecast in science is, therefore, like a shot fired at an unseen target; the starting-point is clear, but afterwards we enter into unknown country, and next to nothing is really known of remote epochs in the future. Many great prophecies, such as the 'heat death' theory, representative of what has been put forth in the name of mathematical certainty, are only of value scientifically if they are certain; but as science advances and ideas change, are they certain? A distinction should be made between the immediate applications of science and the wider claims that are sometimes made for it, and scientific forecast should be taken with a grain of the salt of common sense. Scientific workers, however, realise that all they really know is due to men like Faraday and Einstein, who do not think of practical results. The theoretical mind is the soul of science-the prophetic soul dreaming of things to come; but one should read any scientific forecast as one would read an imaginative poem.

\section{Institute of Chemistry}

Ar the fifty-fourth annual general meeting of the Institute of Chemistry, held on March 1, the president, Dr. G. C. Clayton, presented the Meldola Medal, the gift of the Society of Maccabæans, to Dr. G. F. Marrian, of University College, London, in recognition of his researches on vitamins and hormones. In moving the adoption of the Report of the Council, Dr. Clayton said that the roll of fellows and associates of the Institute now exceeds six thousand. The proposal to petition for a supplemental Royal charter, with the view of securing for members the use of the title "Chartered Chemist", has been postponed. The examinations arranged by the Board of Education and the Institute jointly for National Certificates in Chemistry are proving of real value in co-ordinating and raising the standard of chemical training in technical colleges. Referring to the separate publication of various lectures, including Sir Frank Smith's Gluckstein memorial lecture on "Chemistry and the Community", Dr. Clayton emphasised Sir Frank Smith's view that, even in these difficult times, chemical research must be continued. New problems are awaiting solution, and many which have been solved are yet to be developed on the large scale. Chemieal industry is an excellent barometer for indicating the outlook in industry generally, because it supplies some of the materials required for so many industries, and signs of a change for the better are not lacking. The Appointments Register Committee of the Institute reports that about 190 (or rather more than 3 per cent) of the members are without appointments; the number of unemployed qualified professional chemists in Germany is 1500 out of about 10,000 (15 per cent). Dr. G. C. Clayton was re-clected president of the Institute.

\section{Education in Public Schools}

The headmaster of Eton gave a very interesting and suggestive address, which has recently been printed, on "The Education of the Average Man", at the Royal Institution on Dec. 18. His humour and open mindedness, and his wide and special knowledge of the public schoolboy, command a sympathetic hearing for his views; and with the general tenor of them most people will agree. Hè deplores the constriction caused by the examination system; thinks the boys are called upon for a sort of allround specialism which it is impossible to achieve and is calculated mainly to engender a distaste for further learning, and would himself lay stress on three great aims-accuracy, curiosity, and observation. He speaks frankly as the spokesman of the public schools, which he describes as lying between the upper and nether millstones of the preparatory schools and the university examiners. In all of this there is much sound eriticism and good sense; but one is bound to recognise the limitations of Dr. Alington's point of view. $\mathrm{He}$ is almost entirely critical, except of these public schools which are to him the one virtuous element struggling with adversity, and he is also almost entirely laudator temporis acti; the older system, as he hirnself knew it, seems almost always preferable.

WIтH all possible sympathy and thanks, one must put one or two larger questions than Dr. Alington has raised. Is he really content with the ideal that the education of the élite of the young men of Great Britain should go on indefinitely on the lines of a simple bifurcation of 'sides' as between classics and mathematics, which is what he seems to imply? The classics boy, which is what he was himself, is not to be bothered with the algebra which he cannot understand, and is to have some general or recreative lessons or lectures on science, literature, and history. Would he not agree that with improved methods far more might be done without distaste or overloading, and, in particular, that a modicum of mathematics is desirable for the average boy, this modicum to include an introduction to the calculus? As to history and literature we are inclined to agree with him that they are not suitable subjects for examination, certainly not for the present type of examination. But as to the scope of the history taught we should go much further than he suggests. History and the historical spirit are in fact the new element in human thought, which is bound to become, we will not say dominant, but reconciling, in the increasing complexity of the curriculum. Through that alone we may hope to gain some harmony and a simplication of the mass of knowledge we have to face.

No. 3254, VoL. 129] 